

\title{
Selective Extraction and Purification of Papain Using Polyethylene Glycol (PEG 4000)/Potassium Citrate Aqueous Two Phase
}

\author{
YANMIN LU
}

Shandong Provincial Key Laboratory of Fine Chemicals, College of Food and Bioengineering, Qilu University of Technology, Jinan 250353, Shandong Province, P.R. China

Corresponding author: Fax: +86 531 89631191; Tel: +86 15864538323; E-mail: luyanmin@ mail.sdu.edu.cn

\begin{abstract}
Mathematical models concerning the purification of papain from the crude papain in an aqueous two-phase system which are composed of polyethylene glycol (PEG 4000)/potassium citrate are established with response surface methodology. The concentration of PEG 4000 and potassium citrate, the concentration of additional salt $(\mathrm{KCl})$, the temperature and $\mathrm{pH}$ on the papain purification have been investigated. Results showed that papain tends to partitions to the more hydrophilic salt-rich phase. The steepest ascent method was used to locate the optimal domain. Papain was successfully extracted to the bottom phase of a system composed of $15 \%$ (w/w) PEG $4000,17 \%$ (w/w) citrate and $5.0 \%(\mathrm{w} / \mathrm{w}) \mathrm{KCl}$ at $\mathrm{pH} 5.0$ and $30{ }^{\circ} \mathrm{C}$. Under those conditions, the specific activity, purification factor and activity yield for papain were $1703.02 \mathrm{U} / \mathrm{mg}, 1.89$ and $94 \%$, respectively. The purity of extracted papain was confirmed by SDS-PAGE analysis.
\end{abstract}

Keywords: Aqueous two-phase system, Papain, Purification, Fractional factorial design, Response surface methodology.

\section{INTRODUCTION}

Papain is an enzyme which is found naturally in unripe papayas. This enzyme has a number of interesting applications in cell isolation, leather, cosmetic, textiles, detergents, food and pharmaceutical industries ${ }^{1-3}$. Papain is usually produced as a crude, dried material by collecting the latex from the fruit of the papaya tree. However, the purified enzyme using traditional methods still remains problematic or it is contaminated with other proteases and cannot be used in certain pharmaceutical applications ${ }^{4-6}$. A purification step is necessary to remove contamination. This purification consists of the solubilization and extraction of the active papain. Different methods, such as precipitation methods $s^{7,8}$ and chromatography methods ${ }^{9-12}$, can be applied to purify papain from papaya latex. However, the purified enzyme still remains contaminated by other proteases and the initial processing of the latex is essential before samples are applied on a chromatography column ${ }^{4}$. It is desirable to develop new techniques that either improve or totally or partially replace some stages of the current purification procedures.

Aqueous two-phase extraction has been proved to be a versatile technique for separating and purifying mixtures of biomolecules. Compared to other separation techniques, aqueous two phase extraction offers many advantages such as biocompatible environment for the biomolecules, ease of scale- up, lower interfacial tension and scope for continuous operation $^{13-17}$. As a pioneering work, PEG-phosphate system has been reported for separation and purification of papain from papaya latex ${ }^{18}$. The papain was extracted to the PEG rich phase by modifying PEG with Procion Blue. In polyethylene glycol and ammonium sulfate system, Reactive Red 120 was added to the aqueous two-phase system as a free affinity dye ligand ${ }^{6}$. Papain was obtained in the PEG rich phase. However, the yield was low $(50.6 \%)$. In the present work, as an effective alternative, aqueous two phase extraction was attempted for the separation and purification of papain from the crude papain. As the citrate anion is both biodegradable and nontoxic ${ }^{19}$, we employed potassium citrate as a substitute for phosphate and sulfate salts. Moreover, the structure-making anions, $\mathrm{C}_{6} \mathrm{H}_{5} \mathrm{O}_{7}{ }^{3-}$ which exhibit stronger interaction with water molecules, are beneficial to the aqueous two-phase system formation ${ }^{20}$.

In present work, a detailed study was carried out for the purification of papain using polyethylene glycol (PEG 4000)/ potassium citrate aqueous two-phase system. The optimum conditions were achieved with less cost and shorter time using response surface methodology (RSM). The papain was obtained in the bottom phase and the majority of other protein contaminats were extracted in the other phase in a single step. PEG 4000/potassium citrate aqueous two-phase system is used to purify papain from the crude papain successfully with the specific activity $1703.02 \mathrm{U} / \mathrm{mg}$ and activity yield of $94 \%$. 


\section{EXPERIMENTAL}

Crude papain was provided by Nanning Dongheng Huadao Biotechnology Limited Company. Potassium citrate, citric acid, tris(hydroxymethyl)aminomethane, trichloroacetic acid (TCA), coomassie Blue G250 and R250 were purchased from Sinopharm Chemical Reagent Co., Ltd.. papain, L-tyrosine and casein were purchased from Sigma. PEG (Kermel), Lcystesine (Jpana), EDTA disodium salts (Tieta, Shandong Laiyang) were used without further purification. All the reagents were of analytical grade. Pure water was used throughout.

Preparation of the papain solution and aqueous twophase systems (ATPS): The potassium citrate buffers were prepared by adding a small amount of $50 \%(\mathrm{w} / \mathrm{w})$ citric acid solution to $50 \%(\mathrm{w} / \mathrm{w})$ potassium citrate solution to reach the desired $\mathrm{pH}$. Aqueous two-phase systems were prepared by mixing appropriate amounts of $50 \%$ (w/w) PEG 4000 stock solution, $50 \%(\mathrm{w} / \mathrm{w})$ potassium citrate buffer solution, papain solution and water in order to achieve the desired final system composition. All the systems were mixed using a vortex mixer and centrifuged for $10 \mathrm{~min}$ at $1500 \mathrm{rpm}$ after placed at a certain temperature for $30 \mathrm{~min}$. The volume of each phase was measured when the system turned clear. Top and bottom phases were separated with pipettes. The protein concentration and protease activity of those two phases were assayed separately.

The activity partition coefficient $\left(\mathrm{K}_{\mathrm{a}}\right)$ was defined as the ratio of enzyme activity $(\mathrm{U} / \mathrm{mL})$ in the top phase to that in the bottom phase. The activity yield $\left(\mathrm{Y}_{\mathrm{a}}\right)$ was determined as the ratio of the total activity in the top phase to that in the initial extract. The specific activity (A) was expressed in units per milligram of protein $(\mathrm{U} / \mathrm{mg})$ in the top phase. The purification factor $(\mathrm{PF})$ was calculated as the ratio of the specific activity in the bottom phase to the specific activity in the crud papain.

Analytical methods: The protein concentration was determined by the Bradford method ${ }^{21}$ using Coomassie Blue
G250 with bovine serum albumin (BSA) as the standard. The optical density was measured at $595 \mathrm{~nm}$. Proteolytic activity was assayed by method of Arnon ${ }^{22}$ with slight modification. The reaction mixture (containing $200 \mu \mathrm{L}$ of enzyme solution, $400 \mu \mathrm{L}$ of $50 \mathrm{mM}$ Tris- $\mathrm{HCl}$ buffer $\mathrm{pH} 7$ and $50 \mathrm{mM}$ cysteine$20 \mathrm{mM}$ EDTA disodium salts $\mathrm{pH}$ 7) was incubated at $37^{\circ} \mathrm{C}$ for $5 \mathrm{~min}$. Then $2 \mathrm{~mL}$ of $1 \%(\mathrm{w} / \mathrm{v})$ casein was added to start the reaction. After $10 \mathrm{~min}$, the reaction was stopped by adding $6 \mathrm{~mL}$ of $5 \%(\mathrm{w} / \mathrm{v})$ trichloro acetic acid (TCA) and then placed for $1 \mathrm{~h}$ at room temperature. The precipitate was separated by centrifugation. The absorbance of the supernatant fluid was measured at $275 \mathrm{~nm}$. The blank sample was prepared with addition of trichloro acetic acid, followed by the enzyme. One unit (U) of proteolytic activity was expressed as the amount of enzyme which produced $1 \mu \mathrm{mol}$ tyrosine $\mathrm{min}^{-1} \mathrm{~mL}^{-1}$.

Electrophoresis: The sodium dodecyl sulfate polyacrylamide gel electrophoresis (SDS-PAGE) was carried out according to the method of Laemmli ${ }^{23}$, using a $12 \%$ polyacrylamide separating gel and a $5 \%$ stacking gel. Commercial pure papain (Sigma) was used to identify the papain bands. Electrophoresis was run at a constant voltage of $100 \mathrm{~V}$. The protein samples migrated towards the cathode during electrophoresis. Proteins bands were stained with Coomassie Blue R250 according to the method of Meyer et al. ${ }^{24}$.

\section{RESULTS AND DISCUSSION}

The five factors which were considered to affect the protein purification in the aqueous two-phase system systems were the concentration of PEG $4000\left(\mathrm{X}_{1}\right)$, the concentration of potassium citrate $\left(\mathrm{X}_{2}\right)$, the concentration of potassium chloride $\left(\mathrm{X}_{3}\right), \mathrm{pH}\left(\mathrm{X}_{4}\right)$ and temperature $\left(\mathrm{X}_{5}\right)$. The central composite face-centred design (CCF) was applied using SAS software (Version 9.2 in Windows). The details of the design and result are shown in Table-1. The linear regression equations for the

\begin{tabular}{|c|c|c|c|c|c|c|c|c|c|}
\hline \multicolumn{10}{|c|}{$\begin{array}{l}\text { TABLE-1 } \\
\text { CONDITIONS AND RESULTS OF THE FRACTIONAL FACTORIAL DESIGN SELECTED FOR } \\
\text { PAPAIN EXTRACTION BY PEG4000/POTASSIUM CITRATE AQUEOUS TWO-PHASE SYSTEMS }\end{array}$} \\
\hline Run & $\mathrm{X}_{1}^{\mathrm{a}}(\%)$ & $\mathrm{X}_{2}^{\mathrm{b}}(\%)$ & $\mathrm{X}_{3}^{\mathrm{c}}(\%)$ & $\mathrm{X}_{4}^{\mathrm{d}}$ & $\mathrm{X}_{5}^{\mathrm{e}}(\mathrm{K})$ & $\mathrm{K}_{\mathrm{a}}^{\mathrm{f}}$ & $\mathrm{A}^{\mathrm{g}}(\mathrm{U} / \mathrm{mg})$ & $\mathrm{Y}_{\mathrm{a}}^{\mathrm{h}}(\%)$ & $\mathrm{PF}^{\mathrm{i}}$ \\
\hline 1 & 15 & 15 & 0 & 5 & 323 & 0.46 & 1506.74 & 72 & 1.67 \\
\hline 2 & 21 & 15 & 0 & 5 & 303 & 0.49 & 1317.63 & 37 & 1.46 \\
\hline 3 & 15 & 19 & 0 & 5 & 303 & 0.45 & 1344.88 & 72 & 1.49 \\
\hline 4 & 21 & 19 & 0 & 5 & 323 & 0.96 & 1211.64 & 58 & 1.34 \\
\hline 5 & 15 & 15 & 8 & 5 & 303 & 1.91 & 671.27 & 34 & 0.75 \\
\hline 6 & 21 & 15 & 8 & 5 & 323 & 1.58 & 763.87 & 41 & 0.85 \\
\hline 7 & 15 & 19 & 8 & 5 & 323 & 1.90 & 577.29 & 37 & 0.64 \\
\hline 8 & 21 & 19 & 8 & 5 & 303 & 11.54 & 103.97 & 5 & 0.12 \\
\hline 9 & 15 & 15 & 0 & 8 & 303 & 0.63 & 1103.47 & 64 & 1.22 \\
\hline 10 & 21 & 15 & 0 & 8 & 323 & 4.14 & 256.65 & 14 & 0.28 \\
\hline 11 & 15 & 19 & 0 & 8 & 323 & 1.14 & 888.51 & 60 & 0.99 \\
\hline 12 & 21 & 19 & 0 & 8 & 303 & 1.09 & 829.80 & 47 & 0.92 \\
\hline 13 & 15 & 15 & 8 & 8 & 323 & 1.28 & 536.85 & 35 & 0.60 \\
\hline 14 & 21 & 15 & 8 & 8 & 303 & - & 0.00 & 0 & 0.00 \\
\hline 15 & 15 & 19 & 8 & 8 & 303 & - & 0.00 & 0 & 0.00 \\
\hline 16 & 21 & 19 & 8 & 8 & 323 & - & 0.00 & 0 & 0.00 \\
\hline 17 & 18 & 17 & 4 & 6.5 & 313 & 0.52 & 1130.12 & 67 & 1.25 \\
\hline 18 & 18 & 17 & 4 & 6.5 & 313 & 0.46 & 994.60 & 59 & 1.10 \\
\hline 21 & 18 & 17 & 4 & 6.5 & 313 & 0.59 & 1065.80 & 63 & 1.18 \\
\hline
\end{tabular}


responses could be obtained from the regression results of fractional factorial experiment (in uncoded levels).

Activity recovery $\left(\mathrm{Y}_{\mathrm{a}}\right)=54.7-3.58 \mathrm{X}_{1}-0.56 \mathrm{X}_{2}-4.25 \mathrm{X}_{3}$

$$
-5.67 X_{4}+0.36 X_{5}
$$

Purification factor $(P F)=3.20-0.050 X_{1}-0.042 X_{2}-$

$$
0.10 \mathrm{X}_{3}-0.18 \mathrm{X}_{4}+0.0026 \mathrm{X}_{5}
$$

In general, the magnitude of the coefficients of the linear regression models could be used to evaluate the contribution of the corresponding independent variables to the dependent variables $^{25}$. The linear regression equations reveal that the concentration of potassium citrate $\left(\mathrm{X}_{2}\right)$ and temperature $\left(\mathrm{X}_{5}\right)$ are the less significant factors for both activity recovery $\left(\mathrm{Y}_{\mathrm{a}}\right)$ and purificatino factor (PF). In the following studies, both of the two factors are fixed at constant value. The factorial analysis of variance in Table- 2 also indicates the concentration of PEG $4000\left(\mathrm{X}_{1}\right)$ and potassium chloride $\left(\mathrm{X}_{3}\right)$ are significant factors $(\mathrm{p}<0.05)$ for $\mathrm{Y}_{\mathrm{a}}$ and the concentration of potassium chloride $\left(\mathrm{X}_{3}\right), \mathrm{pH}\left(\mathrm{X}_{4}\right)$ are found to be significant factors $(\mathrm{p}<0.05)$ for PF. In these cases the 'Pr $>F^{\prime}$ less than 0.05 indicates the particular term is statistically significant ${ }^{26}$.

Path of steepest ascent: According to the regression equations and analysis results from fractional factorial experiment, the path of steepest ascent experiment is to maximize the response. Table-3 displays how the variables should be oriented. The direction of improvement starts from the center point of the fractional factorial experiment and moves away from it. It is obvious that the aqueous two-phase system 6 is up to the general vicinity of the optimum. The activity recovery $\left(\mathrm{Y}_{\mathrm{a}}\right)$ and purification factor (PF) are to $88 \%$ and 1.77, respectively.

Response surface method experiments: A central composite face-centred design (CCF) was employed to optimize the three most significant factors, identified by fractional factorial experiment [PEG 4000 concentration $\left(\mathrm{X}_{1}\right), \mathrm{KCl}$ concentration $\left(\mathrm{X}_{3}\right)$ and $\mathrm{pH}\left(\mathrm{X}_{4}\right)$ ] for enhancing both the recovery and the purification factor. Table-4 shows the design and the results of this experiment. Statistical analysis of papain purification using regression model was checked by the Fisher's F-test for analysis of variance (ANOVA) and the results are shown in Table-5. Moreover, the p-value of the models is inferior to 0.05 , while the $\mathrm{p}$-value of the lack of fit is higher than 0.05 , confirming that all the models are statistically significant with $95 \%$ confidence ${ }^{27}$. The F-values and 'probability $>F^{\prime}$ values of all the regression equations show that these models are significant. The model determination coefficient $\mathrm{R}_{2}$ indicates a good response between model prediction and experimental data $^{28}$. The quadratic models for each response variable, including activity partition coefficient $\left(\mathrm{K}_{\mathrm{a}}\right)$, activity yield $\left(\mathrm{Y}_{\mathrm{a}}\right)$ and purification factor (PF), are given by (in uncoded levels):

$$
\begin{aligned}
\mathrm{K}_{\mathrm{a}}= & 10.69-0.57 \mathrm{X}_{1}-1.66 \mathrm{X}_{3}-1.43 \mathrm{X}_{4}+0.0044 \mathrm{X}_{1}^{2} \\
& +0.042 \mathrm{X}_{1} \mathrm{X}_{3}+0.061 \mathrm{X}_{1} \mathrm{X}_{4}+0.057 \mathrm{X}_{3}^{2}+0.12 \mathrm{X}_{3} \mathrm{X}_{4} \\
& +0.018 \mathrm{X}_{4}^{2}, \mathrm{R}^{2}=92.79 \% \\
\mathrm{Y}_{\mathrm{a}}= & -1675.35+68.43 \mathrm{X}_{1}+109.59 \mathrm{X}_{3}+387.40 \mathrm{X}_{4} \\
& -2.15 \mathrm{X}_{1}^{2}-3.33 \mathrm{X}_{1} \mathrm{X}_{3}+1.88 \mathrm{X}_{1} \mathrm{X}_{4}-1.45 \mathrm{X}_{3}^{2} \\
& -8.1 \mathrm{X}_{3} \mathrm{X}_{4}-36.37 \mathrm{X}_{4}^{2}, \mathrm{R}^{2}=88.18 \% \\
\mathrm{PF}= & -23.44+1.17 \mathrm{X}_{1}+1.89 \mathrm{X}_{3}+4.96 \mathrm{X}_{4}-0.037 \mathrm{X}_{12} \\
& -0.066 \mathrm{X}_{1} \mathrm{X}_{3}+0.046 \mathrm{X}_{1} \mathrm{X}_{4}-0.015 \mathrm{X}_{3}^{2} \\
& -0.13 \mathrm{X}_{3} \mathrm{X}_{4}-0.52 \mathrm{X}_{4}^{2}, \mathrm{R}^{2}=83.5 \%
\end{aligned}
$$

Response surface plots were obtained for the measured

\begin{tabular}{|c|c|c|c|c|c|c|c|}
\hline Run & $\mathrm{X}_{1}^{\mathrm{a}}(\%)$ & $\mathrm{X}_{3}^{\mathrm{b}}(\%)$ & $\mathrm{X}_{4}^{\mathrm{c}}$ & $\mathrm{K}_{\mathrm{a}}^{\mathrm{d}}$ & $\mathrm{A}^{\mathrm{e}}(\mathrm{U} / \mathrm{mg})$ & $\mathrm{Y}_{\mathrm{a}}^{\mathrm{f}}(\%)$ & $\mathrm{PF}^{\mathrm{g}}$ \\
\hline 1 & 18.00 & 4.00 & 6.50 & 0.50 & 1331.60 & 83 & 1.48 \\
\hline 2 & 17.80 & 3.70 & 6.30 & 0.53 & 1311.73 & 78 & 1.46 \\
\hline 3 & 17.60 & 3.40 & 6.10 & 0.47 & 1313.40 & 78 & 1.46 \\
\hline 4 & 17.40 & 3.10 & 5.90 & 0.43 & 1459.29 & 84 & 1.62 \\
\hline 5 & 17.20 & 2.80 & 5.70 & 0.40 & 1556.97 & 88 & 1.73 \\
\hline 6 & 17.00 & 2.50 & 5.50 & 0.52 & 1594.89 & 88 & 1.77 \\
\hline 7 & 16.80 & 2.20 & 5.30 & 0.52 & 1583.01 & 85 & 1.76 \\
\hline 8 & 16.60 & 1.90 & 5.10 & 0.50 & 1583.48 & 80 & 1.76 \\
\hline 9 & 16.40 & 1.60 & 4.90 & 0.46 & 1385.09 & 64 & 1.54 \\
\hline 10 & 16.20 & 1.30 & 4.70 & 0.69 & 1434.84 & 55 & 1.59 \\
\hline 11 & 16.00 & 1.00 & 4.50 & 0.57 & 1217.91 & 17 & 1.35 \\
\hline
\end{tabular}
responses based on the experimental model. These plots provide a method to visualize the relationship between responses and experimental levels of each variable as well as the type of interactions between two test variables ${ }^{6,29}$. With only three variables, it is possible to obtain numerous response surfaces.

\begin{tabular}{ccccc}
\multicolumn{5}{c}{ TABLE-2 } \\
\multicolumn{5}{c}{ EFFECTS OF DIFFERENT FACTORS FOR $\mathrm{Y}_{\mathrm{a}}$ AND PF } \\
\hline Variables & \multicolumn{2}{c}{ Test of significance $\left(\mathrm{Y}_{\mathrm{a}}\right)^{\mathrm{a}}$} & \multicolumn{1}{c}{ Test of significance $(\mathrm{PF})^{\mathrm{b}}$} \\
\hline Code & $\mathrm{t}$ & $\mathrm{Pr}>\mathrm{tt}$ & $\mathrm{t}$ & $\mathrm{Pr}>\mathrm{t} \mid$ \\
$\mathrm{X}_{1}^{\mathrm{c}}$ & -2.47117 & 0.0281 & -2.0261 & 0.0638 \\
$\mathrm{X}_{2}{ }^{\mathrm{d}}$ & -0.25861 & 0.8000 & -1.13361 & 0.2774 \\
$\mathrm{X}_{3}$ & -3.90789 & 0.0018 & -5.48307 & 0.0001 \\
$\mathrm{X}_{4}{ }^{\mathrm{e}}$ & -1.95395 & 0.0726 & -3.66604 & 0.0028 \\
$\mathrm{X}_{5}{ }^{\mathrm{g}}$ & 0.833301 & 0.4197 & 0.349908 & 0.7320 \\
\hline
\end{tabular}

${ }^{a} Y_{a}$ : activity yield in the bottom phase, ${ }^{b} \mathrm{PF}$ : purification factor in the bottom phase, ${ }^{c} \mathrm{X}_{1}$ : PEG 4000 concentration $(\mathrm{w} / \mathrm{w}),{ }^{\mathrm{d}} \mathrm{X}_{2}$ : potassium citrate concentration $(\mathrm{w} / \mathrm{w}),{ }^{\mathrm{e}} \mathrm{X}_{3}$ : potassium chloride concentration $(\mathrm{w} / \mathrm{w}),{ }^{\mathrm{f}} \mathrm{X}_{4}$ : $\mathrm{pH},{ }^{g} \mathrm{X}_{5}$ : temperature

TABLE-3

EXPERIMENTAL DESIGN OF THE ASCENT AND CORRESPONDING RESULTS

${ }^{\mathrm{a}} \mathrm{X}_{1}$ : PEG 4000 concentration $(\mathrm{w} / \mathrm{w}),{ }^{\mathrm{b}} \mathrm{X}_{3}$ : potassium chloride concentration $(\mathrm{w} / \mathrm{w}),{ }^{\mathrm{c}} \mathrm{X}_{4}: \mathrm{pH} ; \mathrm{K}_{\mathrm{a}}$ : activity partition coefficient, ${ }^{\mathrm{d}} \mathrm{K}_{\mathrm{a}}$ : activity partition coefficient, ${ }^{\mathrm{e}} \mathrm{A}$ : protease activity in the bottom phase, ${ }^{\mathrm{f}} \mathrm{Y}_{\mathrm{a}}$ : activity yield in the bottom phase, ${ }^{\mathrm{g}} \mathrm{PF}$ : purification factor in the bottom phase 


\begin{tabular}{|c|c|c|c|c|c|c|c|}
\hline \multicolumn{8}{|c|}{$\begin{array}{l}\text { TABLE-4 } \\
\text { UNCODED VALUES OF THE VARIABLES USED IN THE DIFFERENT EXPERIMENTAL ASSAYS OF THE } \\
\text { CENTRAL COMPOSITE DESIGN AND THE CORRESPONDING EXPERIMENTAL RESULTS }\end{array}$} \\
\hline Run & $\mathrm{X}_{1}^{\mathrm{a}}(\%)$ & $\mathrm{X}_{3}^{\mathrm{b}}(\%)$ & $\mathrm{X}_{4}{ }^{\mathrm{c}}$ & $\mathrm{K}_{\mathrm{a}}^{\mathrm{d}}$ & $\mathrm{A}^{\mathrm{e}}(\mathrm{U} / \mathrm{mg})$ & $\mathrm{Y}_{\mathrm{a}}^{\mathrm{f}}(\%)$ & $\mathrm{PF}^{\mathrm{g}}$ \\
\hline 1 & 15 & 0 & 5 & 0.82 & 1048.40 & 41 & 1.16 \\
\hline 2 & 19 & 0 & 5 & 0.48 & 1306.52 & 50 & 1.45 \\
\hline 3 & 15 & 5 & 5 & 0.38 & 1765.01 & 97 & 1.96 \\
\hline 4 & 19 & 5 & 5 & 0.58 & 1142.02 & 55 & 1.27 \\
\hline 5 & 15 & 0 & 6 & 0.71 & 766.44 & 44 & 0.85 \\
\hline 6 & 19 & 0 & 6 & 0.31 & 1498.98 & 76 & 1.66 \\
\hline 7 & 15 & 5 & 6 & 0.59 & 1209.25 & 75 & 1.34 \\
\hline 8 & 19 & 5 & 6 & 1.33 & 441.66 & 25 & 0.49 \\
\hline 9 & 15 & 2.5 & 5.5 & 0.25 & 1350.33 & 80 & 1.50 \\
\hline 10 & 19 & 2.5 & 5.5 & 0.31 & 1516.73 & 79 & 1.68 \\
\hline 11 & 17 & 0 & 5.5 & 0.64 & 1650.02 & 84 & 1.83 \\
\hline 13 & 17 & 2.5 & 5 & 0.32 & 1379.25 & 70 & 1.53 \\
\hline 14 & 17 & 2.5 & 6 & 0.22 & 1524.17 & 88 & 1.69 \\
\hline 15 & 17 & 2.5 & 5.5 & 0.26 & 1389.18 & 76 & 1.54 \\
\hline 16 & 17 & 2.5 & 5.5 & 0.25 & 1480.20 & 81 & 1.64 \\
\hline 17 & 17 & 2.5 & 5.5 & 0.32 & 1360.98 & 75 & 1.51 \\
\hline
\end{tabular}

${ }^{\mathrm{a}} \mathrm{X}_{1}$ : PEG 4000 concentration $(\mathrm{w} / \mathrm{w}),{ }^{b} \mathrm{X}_{3}$ : potassium chloride concentration $(\mathrm{w} / \mathrm{w}),{ }^{c} \mathrm{X}_{4}: \mathrm{pH},{ }^{\mathrm{d}} \mathrm{K}_{\mathrm{a}}$ : activity partition coefficient, ${ }^{\mathrm{e}} \mathrm{A}$ : protease activity in the bottom phase, ${ }^{\mathrm{f}} \mathrm{Y}_{\mathrm{a}}$ : activity yield in the bottom phase, ${ }^{\mathrm{g}} \mathrm{PF}$ : purification factor in the bottom phase

TABLE-5

ANALYSIS OF VARIANCE (ANOVA) FOR THE QUADRATIC MODELS PREDICTED FOR EACH RESPONSE VARIABLE

\begin{tabular}{|c|c|c|c|c|c|c|}
\hline $\begin{array}{l}\text { Response } \\
\text { variable }\end{array}$ & soure & DF & SS & MS & F & $\operatorname{Pr}>\mathrm{F}$ \\
\hline \multirow{5}{*}{$\mathrm{K}_{\mathrm{a}}^{\mathrm{a}}$} & Model & 9 & 1.197314 & 0.133035 & 10.00664 & 0.0031 \\
\hline & Error & 7 & 0.093063 & 0.013295 & \multirow{4}{*}{13.78427} & \multirow{4}{*}{0.0690} \\
\hline & Lack of fit & 5 & 0.090438 & 0.018088 & & \\
\hline & Pure error & 2 & 0.002624 & 0.001312 & & \\
\hline & Total & 16 & 1.290376 & & & \\
\hline \multirow{5}{*}{$\mathrm{Y}_{\mathrm{a}}^{\mathrm{b}}$} & Model & 9 & 5424.732 & 602.748 & \multirow[t]{2}{*}{5.80055} & \multirow[t]{2}{*}{0.0151} \\
\hline & Error & 7 & 727.3856 & 103.9122 & & \\
\hline & Lack of fit & 5 & 654.7189 & 130.9438 & \multirow[t]{3}{*}{3.603957} & \multirow[t]{3}{*}{0.2314} \\
\hline & Pure error & 2 & 72.66667 & 36.3333 & & \\
\hline & Total & 16 & 6152.118 & & & \\
\hline \multirow{5}{*}{$\mathrm{PF}^{\mathrm{c}}$} & Model & 9 & 1.694213 & 0.188246 & \multirow[t]{2}{*}{3.938121} & \multirow[t]{2}{*}{0.042} \\
\hline & Error & 7 & 0.334607 & 0.047801 & & \\
\hline & Lack of fit & 5 & 0.325041 & 0.065008 & \multirow[t]{3}{*}{13.5919} & \multirow[t]{3}{*}{0.0699} \\
\hline & Pure error & 2 & 0.009566 & 0.004783 & & \\
\hline & Total & 16 & 2.02882 & & & \\
\hline
\end{tabular}

The plots that will be shown in this section are those that generated a significant change on the response variables under analysis ${ }^{27}$. The 3D plots are shown in Fig. 1. By analyzing the surface plots, the effects of $\mathrm{KCl}$ concentration and $\mathrm{pH}$ on the response were observed. Fig. 1(a) indicates that the lowest value of $\mathrm{K}_{\mathrm{a}}$ occurs at a low $\mathrm{pH}$ within the range of experimentation. The similar phenomenon has been reported by Ling et al. ${ }^{6}$. Correspondingly, the highest activity recovery was obtained at pH 5.0 in the bottom phase (Fig. 1b). This trend can be interpreted by the net negative charge of the papain surface. According to the previous studies ${ }^{30-32}$, the negatively charged proteins tended to be distributed to the upper phase and the positively charged proteins to the bottom phase in the PEG-salt systems. The response surface plot (Fig. 1c) for the purity of papain in the bottom phase shows that higher purification factors are generally achieved with high concentrations of $\mathrm{KCl}$. This means that the contaminant proteins partition preferentially to the top phase while the papain remains in the bottom phase at the high concentration of $\mathrm{KCl}$. The optimal value of purification factor (1.95) for papain was obtained.

Using a fractional faction design followed by a RSM design, the final optimum values of the parameter are predicted to be at pH 5.0 and $30{ }^{\circ} \mathrm{C}$ containing $15 \%$ (w/w) PEG4000, $17 \%(\mathrm{w} / \mathrm{w})$ potassium citrate, $5 \%(\mathrm{w} / \mathrm{w}) \mathrm{KCl}$. The experiments (seven parallel experiments) were conducted to validate the predicted optimum. The average of activity partition coefficient, specific activity, purification factor and activity recovery for papain in the bottom phase are $0.47,1703 \mathrm{U} / \mathrm{mg}, 1.89$ and $94 \%$, respectively. Values of experimentally determined and statistically predicted responses reveal that the established models fitted well with the experimental data. It indicates that the applied statistical design and modeling is a reliable tool in the designing processes of the investigated aqueous two-phase system $^{33}$. 


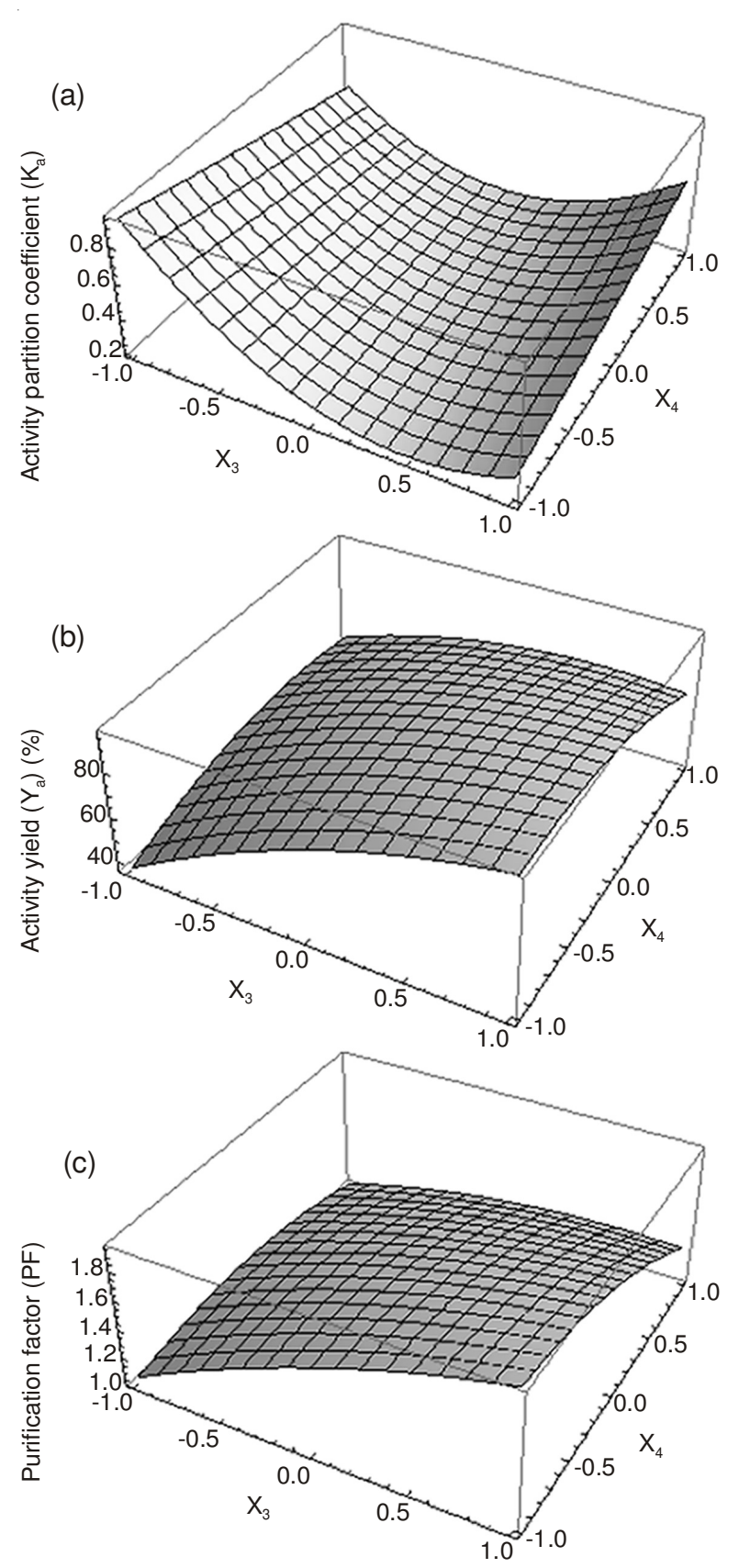

Fig. 1. Response surface plot for a PEG 4000/potassium citrate aqueous two-phase system for the purification of papain. The actual levels corresponding to the coded levels of each variable- $\mathrm{X}_{3}$ : potassium chloride concentration (w/w) (-1: $0,1: 5 \%) ; \mathrm{X}_{4}: \mathrm{pH}(-1: 5,1: 6)$. Other conditions used in the study: $15 \%$ (w/w) PEG 4000; $17 \%$ (w/w) potassium citrate; $\mathrm{T}=30^{\circ} \mathrm{C}$

Evaluation of papain purity by SDS-PAGE: Under the optimal conditions, samples of crude papain, the top and the bottom solutions obtained from the extraction system were identified using SDS-PAGE (Fig. 2). The result (line 3) reveals that the contaminant proteins partitioned to the top PEG-rich phase. Line 4 demonstrates that the papain in the crude papain retained in the bottom phase. The reduction in the number of bands indicates the purity of papain. These results suggested that PEG 4000 / potassium citrate aqueous two-phase system extraction has the potential to be an efficient method and may partially replace some stages of the current purification procedures for purification of papain.



Fig. 2. SDS-PAGE profile of papain during purification by PEG4000/ potassium citrate aqueous two-phase system. Samples on the gel are arranged as followed: (1) papain standard (2) crude papain (3) the PEG-rich phase product after extraction (4) the bottom phase product after extraction.

\section{Conclusion}

PEG 4000/potassium citrate aqueous two-phase system was suitable for papain purification. Three successive experimental designs were employed in the present work to optimize the conditions of papain purification. The feasibility of quadratic models and the optimization of papain purification by the RSM were estimated. The papain was recovered in the bottom phase with an activity yield of $94 \%$ and a purification factor of 1.89. Furthermore, the purity of the papain in the bottom phase was identified by SDS-PAGE. Overall results indicated the excellent separation and purification ability of aqueous two phase extraction for papain without the need of multiple steps.

\section{ACKNOWLEDGEMENTS}

The authors acknowledged the financial support from the National Natural Science Foundation of China (grant no. 21076115).

\section{REFERENCES}

1. C. Qihe, H. Guoqing, J. Yingchun and N. Hui, Food Chem., 98, 624 (2006).

2. $\quad$ S.S. Khaparde and R.S. Singhal, Bioresour. Technol., 78, 1 (2001)

3. I.F. Starley, P. Mohammed, G. Schneider and S.W. Bickle, Burns, 25, 636 (1999).

4. S. Nitsawang, R. Hatti-Kaul and P. Kanasawud, Enzyme Microb. Technol., 39, 1103 (2006).

5. S.N. Su, H.L. Nie, L.M. Zhu and T.X. Chen, Bioresour. Technol., 100, 2336 (2009).

6. Y.-Q. Ling, H.-L. Nie, S.-N. Su, C. Branford-White and L.-M. Zhu, Sep. Purif. Technol., 73, 343 (2010).

7. T.J. Ridgway and G.A. Tucker, Enzyme Microb. Technol., 24, 225 (1999).

8. K.S.M.S. Raghavarao, N.K. Rastogi, M.K. Gowthaman and N.G. Karanth, Adv. Appl. Microbiol., 41, 97 (1995).

9. K. Brocklehurst, J. Carlsson, M.P.J. Kierstan and E.M. Crook, Biochem. J., 133, 573 (1973).

10. D.E. Burke, S.D. Lewis and J.A. Shafer, Arch. Biochem. Biophys., 164, 30 (1974).

11. L. Fukal, J. Kas and E. Paluska, J. Chromatogr. A, 285, 365 (1984).

12. F. D'Souza and A. Lali, Biotechnol. Tech., 13, 59 (1999).

13. M. Li, J.W. Kim and T.L. Peeples, J. Biotechnol., 93, 15 (2002). 
14. P.A. Albertsson, Partitioning of Cell Particles and Macromolecules, Wiley, New York, edn 3 (1986)

15. T.M. Przybycien, N.S. Pujar and L.M. Steele, Curr. Opin. Biotechnol., 15, 469 (2004)

16. J. Thommes and M. Etzel, Biotechnol. Prog., 23, 42 (2007).

17. A.M. Azevedo, A.G. Gomes, P.A.J. Rosa, I.F. Ferreira, A.M.M.O. Pisco and M.R. Aires-Barros, Sep. Purif. Technol., 65, 14 (2009).

18. R. Kuboi, W.H. Wang and I. Komasawa, Kagaku Kogaku Ronbunshu, 16, 772 (1990).

19. J. Vernau and M.R. Kula, Biotechnol. Appl. Biochem., 12, 397 (1990).

20. X.Q. Xie, Y. Wang, J. Han and Y.S. Yan, Anal. Chim. Acta, 687, 61 (2011).

21. M.M. Bradford, Anal. Biochem., 72, 248 (1976).

22. R. Arnon, Methods Enzymol., 19, 226 (1970).

23. U.K. Laemmli, Nature, 227, 680 (1970).

24. T.S. Meyer and B. Lamberts, Biochim. Biophys. Acta, 107, 144 (1965).
25. C.K. Su and B.H. Chiang, Process Biochem., 41, 257 (2006).

26. A.L. Ahmad, C.J.C. Derek and M.M.D. Zulkali, Sep. Purif. Technol., 62, 702 (2008).

27. I.F. Ferreira, A.M. Azevedo, P.A.J. Rosa and M.R. Aires-Barros, J. Chromatogr. A, 1195, 94 (2008).

28. W.B. Zhi, J.N. Song, F. Ouyang and J.X. Bi, J. Biotechnol., 118, 157 (2005).

29. D.L. Qiao, B. Hu, D. Gan, Y. Sun, H. Ye and X.X. Zeng, Carbohydr. Polym., 76, 422 (2009).

30. Y.M. Lu, Y.Z. Yang, X.D. Zhao and C.B. Xia, Food Bioprod. Process., 88, 40 (2010).

31. J.A. Asenjo, A.S. Schmidt, F. Hachem and B.A. Andrews, J. Chromatogr. A, 668, 47 (1994).

32. A.S. Schmidt, A.M. Ventom and J.A. Asenjo, Enzyme Microb. Technol., 16, 131 (1994).

33. M. Antov and R. Omorjan, Bioprocess Biosyst. Eng., 32, 235 (2009). 